\title{
The Effects of Anemia Education Using Web-Based She Smart to Improve Knowledge, Attitudes, and Practice in Adolescent Girls
}

\author{
Ernawati \\ Midwifery Study Program, Graduate School of Hasanuddin University, Makassar, Indonesia \\ Corresponding author email: ernawati19p@student.unhas.ac.id
}

Yusring Sanusi Baso

Learning Media Center, Learning Resource and E-Learning, Hasanuddin University, Makassar, Indonesia

Email: yusring@unhas.ac.id

\section{Healthy Hidayanty}

Department of Nutrition Sciences, Faculty of Public Health, Hasanuddin University, Makassar, Indonesia

Email: hhidayanty@yahoo.com

\section{Syafruddin Syarif}

Department of Electrical Engineering, Faculty of Engineering, Hasanuddin University, Makassar, Indonesia Email: syafruddin.s@eng.unhas.ac.id

\author{
Aminuddin \\ Department of Nutrition, Faculty of Medicine, Hasanuddin University, Makassar, Indonesia \\ Email: aminuddin@med.unhas.ac.id

\section{Burhanuddin Bahar} \\ Department of Nutrition Sciences, Faculty of Public Health, Hasanuddin University, Makassar, Indonesia \\ Email: baharburhanuddin96@gmail.com
}

\begin{abstract}
Anemia is a state of hemoglobin levels in the bloodless than normal numbers according to the sex and age group. The impact of anemia in adolescents is a decrease in achievement and learning spirit and can cause symptoms such as paleness, lethargy, decreased appetite, and growth disorders. Anemia has an impact not only on the health of adolescent girls but can have a long impact on the health of the mother and fetus. You can see the influence of anemia education on knowledge, attitudes, and practice. Uses the Pre-experimental method with the design of one group pretest and posttest. Sampling technique using purposive sampling with the number of 47 adolescent girls. The research was conducted at Senior High School 12 Makassar in September-October 2021. Data analysis using the McNemar test. From the results of statistical tests showed that there was an influence on the use of web-based she smart education model on the use of adolescent girls about anemia with p-value $=0.000(p<0.05)$, attitude $p$-value $=0.016$ ( $p<0.05)$ and action $p$-value $=0.001$ ( $p<0.05)$. Anemia education using web-based she smart can improve knowledge, attitudes, and practice before and after an intervention.
\end{abstract}

Keywords---adolescent girls, anemia, attitudes, education, web-based. 
Introduction

A condition of lack of hemoglobin levels in the blood or blood conditions in the body less than normal according to sex and age is also referred to as anemia (Dunne et al., 2002). The World Health Organization (WHO) sets the standard of anemia in adolescents at $12 \mathrm{~g} / \mathrm{dL}$ for adolescent girls while adolescent boys are $13 \mathrm{~g} / \mathrm{dL}$ (Onabanjo \& Balogun, 2014).

Data on the prevalence of anemia in women of childbearing age in the world in 2015 by $32 \%$, in 2016 increased to $32.8 \%$. WHO is targeted by 2025 a $50 \%$ reduction in the incidence of anemia in women of productive age (WHO, 2019). In Indonesia, the incidence of anemia in adolescent girls aged 15-24 years, according to Basic Health Research in 2013 was $37.1 \%$ and in 2018 there was an increase of $48.9 \%$ (RISKESDAS, 2018). Globally the cause of anemia is due to iron deficiency and other causes i.e. Nutritional deficiencies (such as folate, vitamin A and vitamin B12), acute and chronic inflammation, parasitic infections, and congenital disorders can also cause anemia (Pareek \& Hafiz, 2015).

Menstruation is also one of the causes of anemia, every month adolescent girls will experience menstruation that will cause adolescent girls to lose blood, while the need for iron as a micronutrient in adolescent girls is 3 times greater than in young men, therefore it takes iron for the recovery of the condition of adolescent girls who are not experienced by men (Tarini et al., 2020). The achievement and spirit of learning in adolescent girls is the impact of anemia. The symptoms of anemia are tired, weak, lethargic, tired, weak, decreased appetite, and growth disorders (Ahwal, 2016).

Raise awareness as well as increase adolescent knowledge so that adolescents are more likely to eat iron-rich foods and iron source foods, practice home-cooked food fortification methods, and monitor monthly bleeding (Johnson et al., 2016). In this era of globalization, the use of smartphones as a medium of communication technology gives a fairly important role in human life, one of which targets teenagers who are currently difficult to escape the use of gadgets (Sudiarto et al., 2019).

Some studies say that the use of technology in the field of health can support the improvement of public knowledge about health information so quickly (Yani, 2018). Therefore, an information system is needed that can help teenagers to get access to information about anemia problems in adolescent girls that can be accessed through desktop or mobile phones that do not require certain qualifications or types of mobile phones, large storage capacity and can be reached by everyone (Tefferi, 2003). The program is designed as an E-Learning model that can educate adolescents on the prevention of web-based anemia. Based on the background above, the researchers aim to see the influence of anemia education on the knowledge, attitudes, and practice of adolescent girls (Schinke et al., 2008; Miller \& Gur, 2002; Pate et al., 2009).

\section{Research Methods}

This research uses the Pre-experimental Design method with the type of design used by One Group Pretest-Posttest Design, which is a way that researchers do to find out the state of the subject before and after treatment so that researchers can see the results of comparisons or see changes in the subject (Setiawan \& Prasetyo, 2015). This research was conducted at Senior High School of 12 Makassar in September-October 2021, after getting an ethical Clearance from the ethics committee of the Faculty of Public Health, Hasanuddin University Makassar with number 7399 / UN4.14.1 / TP.01.02 / 2021. The population in this study was all-girls class XI in Senior High School in 12 Makassar which amounted to 152 people.

The sampling technique in this study is Purposive Sampling. The sample in this study was 47 adolescent girls in Senior high school 12 Makassar obtained through the sloven's formula and fulfilled the inclusion of 47 respondents. Data collection techniques are performed using primary data and secondary data. Primary data is obtained directly from adolescent girls to get respondent data. Secondary data is obtained from school reports. Computerized data processing using the SPSS program version 21. Data analysis is done using the McNemar Test. 


\section{Results and Discussion}

Knowledge

Table 1

Influence of She Smart based education on adolescent girls' knowledge of anemia $(\mathrm{n}=47)$

\begin{tabular}{|c|c|c|c|c|c|c|c|}
\hline \multirow{3}{*}{$\begin{array}{l}\text { Pre } \\
\text { Test }\end{array}$} & \multicolumn{6}{|c|}{ Post Test } & \multirow{3}{*}{$P$} \\
\hline & \multicolumn{2}{|c|}{ Good } & \multicolumn{2}{|c|}{ Less } & \multicolumn{2}{|c|}{ Total } & \\
\hline & $\mathrm{N}$ & $\%$ & $\mathrm{~N}$ & $\%$ & $\mathrm{~N}$ & $\%$ & \\
\hline Less & 22 & 46,8 & 1 & 2,1 & 23 & 48,9 & 0,000 \\
\hline Good & 23 & 48,9 & 1 & 2,1 & 24 & 51,1 & \\
\hline Total & 45 & 95,8 & 2 & 4,2 & 47 & 100 & \\
\hline
\end{tabular}

*McNemar Test

The results of statistical tests in table 1 showed that after the intervention, the adolescent who experienced a change in knowledge levels from fewer categories to good as many as 22 people (46.8\%) and good categories to less as many as 1 people $(2.1 \%)$. So the number of students with good knowledge categories as many as 45 people (95.8\%) and fewer knowledge levels as many as 2 people (4.2\%) with a value of $\mathrm{p}$-value $(\mathrm{p}=0,000<\alpha=0.05)$. This study shows that there is an influence on the use of She Smart Education based on adolescent girls' knowledge about Anemia in Senior high school 12 Makassar.

Attitude

Table 2

Influence of She Smart education-based web on adolescent girls' attitudes about anemia $(\mathrm{n}=47)$

\begin{tabular}{|c|c|c|c|c|c|c|c|}
\hline \multirow{3}{*}{$\begin{array}{l}\text { Pre } \\
\text { Test }\end{array}$} & \multicolumn{6}{|c|}{ Post Test } & \multirow{3}{*}{$P$} \\
\hline & \multicolumn{2}{|c|}{ Good } & \multicolumn{2}{|c|}{ Less } & \multicolumn{2}{|c|}{ Total } & \\
\hline & $\mathrm{N}$ & $\%$ & $\mathrm{~N}$ & $\%$ & $\mathrm{~N}$ & $\%$ & \\
\hline Less & 7 & 14,9 & 0 & 0 & 7 & 14,9 & \\
\hline Good & 40 & 85,1 & 0 & 0 & 40 & 85,1 & 0,016 \\
\hline Total & 47 & 100 & 0 & 0 & 47 & 100 & \\
\hline
\end{tabular}

*McNemar Test

The results of statistical tests in table 2 showed that after the intervention, adolescents who experienced a change in attitude from a lesser category to as many as 7 people (14.9\%) and a good category became less non-existent. So there are students with a category of good attitudes as many as 47 people (100\%) and fewer attitudes are not there. Pvalue $(p=0.016<\alpha=0.05)$. This study shows that there is an influence on the use of She Smart Education based on the attitude of adolescent girls about Anemia in Senior High School 12 Makassar.

\section{Practice}

Table 3

Effect of She Smart education based web on adolescent girls' practice on anemia $(n=47)$

\begin{tabular}{lccccccc}
\hline \multirow{2}{*}{$\begin{array}{l}\text { Pre } \\
\text { Test }\end{array}$} & \multicolumn{9}{c}{ Post Test } & \multicolumn{2}{c}{ Total } & \multirow{2}{*}{$P$} \\
\cline { 2 - 6 } & \multicolumn{2}{c}{ Positive } & \multicolumn{2}{c}{ Negative } & \\
\hline Negative & 15 & 31,9 & 21 & 44,7 & 36 & 76,6 & \\
Positive & 10 & 21,3 & 1 & 2,1 & 11 & 23,4 & 0,001 \\
Total & 25 & 53,2 & 22 & 46,8 & 47 & 100 & \\
\hline
\end{tabular}

\footnotetext{
*McNemar test
} 
The results of statistical tests in table 3 showed that after the intervention, adolescents who experienced a change in action from negative to the positive category as many as 15 people $(31.9 \%)$ and positive categories of negative as much as 1 person $(2.1 \%)$. So the number of students with positive action categories as many as 25 people (53.2\%) and negative practice as many as 22 people $(46.8 \%)$. With a value of $=0,000<\alpha=0.05$ ). This study shows that there is an influence on the use of She Smart Education based on the practice of adolescent girls about Anemia in Senior high school 12 Makassar.

\section{The influence of the use of anemia education using web-based She Smart on the knowledge of adolescent girls}

Knowledge is the result of a person's knowledge obtained through the results of sensing, sensing from someone including sight, hearing, smell, taste, and groping (Notoatmodjo, 2014). Adolescent girls' knowledge of anemia becomes a problem that must be solved immediately given the dangers posed by anemia impacting across generations. To reduce the risk of anemia in adolescent girls, an alternative is needed, one of which is education, education is also key because a good understanding of adolescent girls will reduce the incidence of anemia. For the use of educational methods in adolescents, effective it must be packed interestingly and impressively (Styaningrum \& Metty, 2021). This study obtained differences in the knowledge of adolescent girls before and after being given web-based anemia education, media, there was an increase with a value of $p$-value $0,000<0.05$, it can be concluded that web-based anemia education media is significant in increasing the knowledge of adolescent girls (Huang \& Zhao, 2020; Carhart-Harris et al., 2011).

This is in line with research conducted by Hatini \& Noordiati (2021), with the title Utilization of YouTube videos about anemia in adolescents at Vocational School YP SEI Palangkaraya. The results of the analysis obtained $a p$ value of $0,000(\mathrm{p}<0.05)$ which showed video extension interventions improved adolescent years of anemia significantly. This is also in line with research conducted by Moradi et al. (2017), which said that the Effect of webbased education on knowledge and preventive behaviors of iron deficiency anemia (IDA), showed the results that the educational program based on is Web increased knowledge of iron deficiency anemia prevention in adolescent girls (Farooqui et al., 2018).

Knowledge can affect a person's attitude, with good knowledge, it will be realized a good attitude, vice versa. This web as an educational medium plays a role to change one's knowledge, attitudes and practice (Jacelon, 2002; Kristeller \& Hoerr, 1997). The expected change is to maintain and improve insight and awareness about anemia so that a person can prevent the risk of anemia and protect themselves from the threat of anemia.

\section{The effect of the use of anemia education using web-based She Smart on the attitudes of adolescent girls}

Attitude is the readiness or willingness of a person to behave or respond to something both to positive and negative stimuli from an object of stimulation. Attitude influenced by knowledge, good knowledge will encourage a person to display an attitude that is by his knowledge that has been obtained (Notoatmodjo, 2012).

In this study, there were differences in the attitude of adolescent girls before and after being given web-based anemia education, media with a value of $p$-value $0,016<0.05$, it can be concluded that web-based anemia education media is significant in improving the attitude of adolescent girls. This is in line with research conducted by Fitriani et al. (2019), which states that there is an influence on the extension of nutritional anemia with motion video media with attitudes. Adolescent girls at Bina Muda High School. With the gain, p-value 0.001<0.05. This research is also in line with research conducted by Saraswati et al. (2020), on the Influence of Android Applications Aneminfo On The Attitudes of Adolescent girls Related to Iron Deficiency Anemia.

This study implies that it is easy to study anemia material and proven to increase changes in the attitudes of adolescent girls so that the web is considered worthy and effective as an educational medium (Muslimin et al., 2022). The existence of anemia education can play a role to change the attitudes of individuals/ adolescents and society in general by health values. The expected change in attitude is to maintain and increase adolescent awareness to prevent the risk of anemia and can protect yourself from the threat of anemia.

\section{The influence of the use of anemia education using web-based She Smart on the practice of adolescent girls}

Action is a person's response to a stimulus. Once one knows the object, then assesses what is known, the next process is expected that one will carry out what he knows or addressed (Notoatmodjo, 2012). In this study, there were differences in the practice of adolescent girls before and after being given web-based anemia education, media with a value of $p$-value $0.001<0.05$, it can be concluded that web-based anemia education media is significant in improving the practice of adolescent girls (Neff et al., 2002). This is in line with research conducted by Jalambo et 
al. (2017), on Improving Knowledge, Attitudes, and Practice of Iron Deficiency Anemia After Nutritional Intervention with the results of the action increased before the intervention $54.5 \%$ increased to $75.5 \%$ after the intervention. This is also in line with research conducted by Abu-Baker et al. (2021), on the Effect of Nutritional Education on Knowledge, Attitudes, and Practice Related to Iron Deficiency Anemia in Adolescent Girls in Jordan with action results of $42.7 \%$ after intervention $63.8 \%$ Total score in the intervention group showed a significant increase from pre to post-test.

This is in line with research conducted by Lathifa \& Mahmudiono (2020), The Influence of Web-Based Nutrition Education Media in Adolescent Balanced Nutrition Eating Behavior sin Senior high school Surabaya, The results showed that most respondents acted well (94.4\%). the influence of web media on the typing of balanced nutrition with a $p$-value of balanced nutritional practices $(p=0.000)$.

Web-based She Smart educational interventions for anemia education in adolescent girls can have a positive impact and effectively improve knowledge, attitudes, and practice about anemia in adolescent girls (Primadewi \& Diwyami, 2021). Professional health care should not only be oriented towards health problems among adolescent groups but should also be supported to be applied to school regulations so that anemia can be prevented as early as possible.

\section{Conclusion}

Anemia education using web-based she smart can improve knowledge, attitudes, and practice before and after the intervention in adolescent girls in senior high school 12 Makassar.

\section{Acknowledgments}

The researcher would like to express her thankfulness to all the staff and lecturers who helped the researcher by permitting her to do her research from September to October 2021 toward the student SMA Negeri 12 Makassar.

\section{References}

Abu-Baker, N. N., Eyadat, A. M., \& Khamaiseh, A. M. (2021). The impact of nutrition education on knowledge, attitude, and practice regarding iron deficiency anemia among female adolescent students in Jordan. Hellion, 7(2). https://doi.org/10.1016/j.heliyon.2021.e06348

Ahwal, S. (2016). A study to assess the knowledge and prevalence of iron deficiency anemia among adolescent girls in a selected college of New Delhi. Journal of Nursing Science \& Practice, 6(3), 57-60.

Carhart-Harris, R. L., King, L. A., \& Nutt, D. J. (2011). A web-based survey on mephedrone. Drug and alcohol dependence, 118(1), 19-22. https://doi.org/10.1016/j.drugalcdep.2011.02.011

Dunne, J. R., Malone, D., Tracy, J. K., Gannon, C., \& Napolitano, L. M. (2002). Perioperative anemia: an independent risk factor for infection, mortality, and resource utilization in surgery. Journal of Surgical Research, 102(2), 237-244. https://doi.org/10.1006/jsre.2001.6330

Farooqui, N., Bansal, A., \& Agarwal, A. K. (2018). Impact of financial aid as scholarships on educational attainment \& quality of life among Muslim adolescent girls in madrasas. International Journal of Health \& Medical Sciences, 1(1), 1-9. https://doi.org/10.31295/ijhms.v1n1.33

Fitriani, S. D., Umamah, R., Rosmana, D., Rahmat, M., \& Mulyo, G. P. E. (2019). Penyuluhan Anemia Gizi Dengan Media Motion Video Terhadap Pengetahuan Dan Sikap Remaja Putri. Jurnal Riset Kesehatan Poltekkes Depkes Bandung, 11(1), 97-104.

Hafid, R. N. H., Baso, Y. S., Ramadany, S., Manapa, E. S., \& Tamar, M. (2021). The difference of satisfaction level of midwifery students in trying out competency test with computer-based test and web-based test. International Journal of Health \& Medical Sciences, 4(1), 8-14.

Hatini, E. E., \& Noordiati, N. (2021). Pemanfaatan Video YouTube tentang Anemia pada Remaja Putri di SMK YPSEI Palangka Raya. Jurnal Surya Medika (JSM), 6(2), 53-60.

Huang, Y., \& Zhao, N. (2020). Generalized anxiety disorder, depressive symptoms and sleep quality during COVID19 outbreak in China: a web-based cross-sectional survey. Psychiatry research, 288, 112954. https://doi.org/10.1016/j.psychres.2020.112954

Jacelon, C. S. (2002). Attitudes and behaviors of hospital staff toward elders in an acute care setting. Applied Nursing Research, 15(4), 227-234. https://doi.org/10.1053/apnr.2002.35958

Jalambo, M. O., Sharif, R., Naser, I. A., \& Karim, N. A. (2017). Improvement in knowledge, attitude and practice of iron deficiency anaemia among iron-deficient female adolescents after nutritional educational intervention. Global Journal of Health Science, 9(7), 15-23. 
Johnson, N., Noufeena, D. Y., Parvathi, P. J., Aranha, P. R., \& Shetty, A. P. (2016). A study on knowledge regarding prevention of iron deficiency anemia among adolescent girls in selected pre-university colleges of Mangaluru. Int J Cur Res Rev, 8, 18.

Kristeller, J. L., \& Hoerr, R. A. (1997). Physician attitudes toward managing obesity: differences among six specialty groups. Preventive medicine, 26(4), 542-549. https://doi.org/10.1006/pmed.1997.0171

Lathifa, S., \& Mahmudiono, T. (2020). Influence of Web-Based Nutrition Education Media On Balanced Nutrition Eating Behavior Of High School Teenagers Surabaya the Effect of Web-Based Nutrition Education Media Toward Balanced Nutritional Eating Behavior on High. Media Nutrition Kesmas, 9.

Miller, L., \& Gur, M. (2002). Religiousness and sexual responsibility in adolescent girls. Journal of Adolescent Health, 31(5), 401-406. https://doi.org/10.1016/S1054-139X(02)00403-2

Moradi, A., Salimi, M., Esfarjani, S. V., \& Haghighizadeh, M. H. (2017). Effect of Web-based education on knowledge and preventive behaviors of Iron Deficiency Anemia among high school girls. Journal of Clinical and Analytical Medicine, 1, 445.

Muslimin, K. D., Baso, Y. S., Hidayanty, H., Syarif, S., Aminuddin, A., \& Bahar, B. (2022). The effect of HIV/AIDS education prevention using web-based she smart on knowledge, attitudes, and practice in adolescent girls. International Journal of Health \& Medical Sciences, 5(1), 31-36. https://doi.org/10.21744/ijhms.v5n1.1830

Neff, M. M., Turk, E., \& Kalishman, M. (2002). Web-based primer design for single nucleotide polymorphism analysis. TRENDS in Genetics, 18(12), 613-615. https://doi.org/10.1016/S0168-9525(02)02820-2

Notoatmodjo, S. (2012). Health promotion and health behavior. Jakarta: rineka cipta.

Notoatmodjo, S. (2014). Health research methodology. Rineka Cipta.

Onabanjo, O. O., \& Balogun, O. L. (2014). Anthropometric and iron status of adolescents from selected secondary schools in Ogun state, Nigeria. ICAN: Infant, Child, \& Adolescent Nutrition, 6(2), 109-118.

Pareek, P., \& Hafiz, A. (2015). A study on anemia related knowledge among adolescent girls. Int J Nutr Food Sci, 4(3), 273.

Pate, R. R., Stevens, J., Webber, L. S., Dowda, M., Murray, D. M., Young, D. R., \& Going, S. (2009). Age-related change in physical activity in adolescent girls. Journal of Adolescent Health, 44(3), 275-282. https://doi.org/10.1016/j.jadohealth.2008.07.003

Primadewi, K., \& Diwyami, N. P. (2021). Correlation of knowledge and family support to compliance with iron (fe) tablet consumption for pregnant women in preventing anemia: new normal COVID-19 era in working area of health centers south kuta. International Journal of Health Sciences, 5(2), 189-201. https://doi.org/10.29332/ijhs.v5n2.1405

RISKESDAS. (2018). Data of the Year 2018.

Saraswati, R. S., Kartini, A., \& Agushybana, F. (2020). The influence of the android application aneminfo on the knowledge and attitudes of adolescent girls related to iron deficiency anemia. Indonesian Journal of Health Promotion, 15(2), 65-69.

Schinke, S. P., Fang, L., \& Cole, K. C. (2008). Substance use among early adolescent girls: Risk and protective factors. Journal of Adolescent Health, 43(2), 191-194. https://doi.org/10.1016/j.jadohealth.2007.12.014

Setiawan, D., \& Prasetyo, H. (2015). Health research methodology for health students. Graha Science.

Styaningrum, S. D., \& Metty, M. (2021). Healthy Millennial Card Games as an educational medium to prevent anemia in adolescent girls in boarding schools. Indonesian Nutrition Science, 4(2), 171.

Sudiarto, S., Niswah, F. Z., Pranoto, R. E. P., Hanifah, I., Enggardini, A. A., Masruroh, Z., \& Muhammad, H. N. A. (2019). Optimalisasi Pendidikan Kesehatan Kepada Remaja Melalui Aplikasi Android Profoteen. Jurnal Kepemimpinan dan Manajemen Keperawatan, 2(2), 74-79.

Tarini, N. W. D., Sugandini, W., \& Sulyastini, N. K. (2020, January). Prevalence of Anemia and Stunting in Early Adolescent Girls. In 3rd International Conference on Innovative Research Across Disciplines (ICIRAD 2019) (pp. 397-402). Atlantis Press.

Tefferi, A. (2003). Anemia in adults: a contemporary approach to diagnosis. In Mayo Clinic Proceedings (Vol. 78, No. 10, pp. 1274-1280). https://doi.org/10.4065/78.10.1274

WHO. (2019). Data Extract From World Development Indicators. In The World Bank.

Yani, A. (2018). Utilization of Technology in the Health of Community Health. PROMOTIF: Jurnal Kesehatan Masyarakat, 8(1), 97-103. 